\title{
The (Questionable) Importance of New York at the Constitutional Convention
}

\author{
Paul Carlsen
}

Lakeshore Technical College, Cleveland, wI, USA

paul.carlsen@gotoltc.edu

Jac Heckelman

Wake Forest University, Winston-Salem, NC, USA

heckeljc@wfu.edu

\begin{abstract}
The U.s. Constitution was first developed at the 1787 Convention, where each state's vote was determined by the majority preference of its delegates. Two of the delegates from New York, John Lansing and Robert Yates, both strident anti-Federalists, left the Convention early due to disagreement with the proceedings. Their departure cost New York its vote for the rest of the Convention, and has been considered by some scholars to be an important event. We investigate how often New York's vote was critical to proposals passing or failing, both when present and counter-factually when absent. We find New York's vote could have been critical on only 28 of 578 (roughly $5 \%$ ) votes. Most of the 28 votes were on nominal issues. However, paradoxically, it appears that a more favorable outcome for Lansing and Yates might have occurred had New York also missed the very first vote of the Convention and the last vote on apportionment prior to "The Great Compromise".
\end{abstract}

\section{Keywords}

American founding - New York - Great Compromise - constitutional convention

\section{Introduction}

The U.S. Constitution, ratified in 1788, replaced the Articles of Confederation and made sweeping changes to the political institutions of the new federal 
government, creating a federal executive, federal courts, and a bicameral legislature with one chamber based on state population size. It has been widely interpreted as strongly moving power from the states to the federal government granting it new opportunities for taxation, regulation, and enforcement. ${ }^{1}$ Gordon Wood would go as far as to claim "there could be little doubt that the federal Constitution was intended to be, as Oliver Ellsworth said, 'a creation of power' which means a corresponding reduction of those kinds of liberty 'which enervate a necessary government' ... [and was] probably the strongest government that could have been formed." ${ }^{2}$

The Constitution was developed over the course of four months at a special convention held in Philadelphia, which lasted from 30 May-17 September 1787. Twelve of the states sent delegates to the Convention. Rhode Island never attended. Delegate attendance varied. Some delegates, like those from South Carolina, were present every day the Convention was in session. Some delegates experienced conflicts with other duties; for example George Wythe of Virginia left the Convention shortly after it convened to care for his sick wife, and the Pennsylvania delegates, many of whom were concurrently serving in the Pennsylvania legislature, came and went as their schedules allowed. Some delegates left the Convention early specifically because they opposed the direction it was taking while others (Edmond Randolph, George Mason, and Elbridge Gerry) shared similar sentiments but remained throughout the Convention, actively participated, but ultimately refused to sign their name to the final document. Two of the three delegates who left early in opposition, Robert Yates and John Lansing, (the other being Luther Martin from Maryland) represented two of the three New York delegates (with Alexander Hamilton being the third). Yates and Lansing departed the Convention in an outrage after 10 July, missing the final nine weeks. They later helped lead the (ultimately failed) opposition against New York ratifying the Constitution. ${ }^{3}$ In a letter to Governor Clinton in 1787 (published in 1788), Lansing and Yates explained the reasoning of their departure:

1 Beard, Charles A., An Economic Interpretation of the Constitution of the United States (New York: Macmillan Company, 1913 [1939]); Holton, Woody, Unruly Americans and the Origins of the Constitution (New York: Hill and Wang, 2007); McGuire, Robert A., To Form a More Perfect Union, (New York: Oxford University Press, 2003); Young, Alford F., The Democratic Republicans of New York: The Origins 1763-1797, (Chapel Hill: University of North Carolina Press, 1967).

2 Wood, Gordon S., The Creation of the American Republic 1776-1787, (Chapel Hill: University of North Carolina Press, 1969), p. 519.

3 Young, The Democratic Republicans of New York. 
...before we left the convention, its principles were so well established, as to convince us, that no alteration was to be expected, to conform it to our ideas of expediency and safety. A persuasion, that our further attendance would be fruitless and unavailing, rendered us less solicitous to return ${ }^{4}$

The departure of Lansing and Yates from the Convention is particularly noteworthy. Although many delegates left the proceedings at various stages for a variety of reasons, the departure of Lansing and Yates is the only instance of a state permanently losing its voting privilege at the Convention. The departure of Lansing and Yates prevented them not only from voting but also stripped them of the opportunity to engage in discussion and persuasion with the other delegates both on the floor and when the Convention was in recess. (Hamilton, though, would continue to participate in the Convention during his sporadic attendance, by joining debates and various committees, but could not cast a vote for his state.)

Recent scholarship has suggested the departure of Lansing and Yates to be a turning point in the Convention. ${ }^{5}$ Both being staunch anti-Federalists, their departure was argued to have significantly reduced the extent of opposition to developing a stronger new federal government. In addition, the loss of New York's vote presumably reduced the power of the small-state coalition. This suggests that Lansing and Yates engaged in a classic "cutting off their nose to spite their face" paradox. As upset as they may have been with the direction of the Convention, by leaving they could have made the situation even more dire from their perspective, ending up with a final Constitution even more federalist in structure than had they stayed.

Yet assessing the importance of Lansing and Yates has to this point been purely descriptive in nature. Empirical testing has been absent. We present a systematic methodology for determining the importance of these two delegates at the Convention, and their subsequent departure.

One way for a delegate's presence to be important is by being influential through the use of skillful rhetoric which convinces others to change their minds. ${ }^{6}$ We have not found any scholarship suggesting either Lansing or Yates

4 Farrand, Max. The Records of the Federal Convention of 1787 . Revised. Vols. I-IV, (New Haven: Yale Unversity Press, 1937), vol. III, p. 247.

5 Beeman, Richard, Plain, Honest Men: The Making of the American Constitution, (New York: Random House, 2009); McFerren, Warren L., Birth of the Republic: The Origin of the United States, (Sanford, FL: Southern Liberty Press, 2005).

6 Robertson, David, "Madison's Opponents and Constitutional Design" in American Political Science Review 99 (2005): 225-243. 
were particularly influential in this regard. A second manner might entail pushing an agenda by proposing motions which pass, thereby either promoting one's own views or changing wording to successfully block other proposals which run counter to these views. Yet according to the historical record of debates published by Farrand, Lansing was only credited twice for making a motion and both proposals failed; Yates did not make any motions at all. ${ }^{7}$ It would seem, then, that few motions were sacrificed by their absence. A third aspect in which the presence or absence of a delegate could be critical to the proceedings is if they effectively altered proposal vote outcomes while present and/or counter-factually would have impacted proposal outcomes they missed had they stayed. ${ }^{8}$ It is this aspect we focus on here.

Voting at the Convention was conducted by majority rule of states where each state vote was determined by a majority of its present delegates. For specific delegates to impact the outcome of any given proposal, two conditions are necessary. First, their votes must affect their state vote, and second, their state vote must affect passage. For Lansing and Yates in particular, the former is jointly true by definition since there were only three delegates from New York, but the latter would only hold for those proposals which would be reversed depending on New York's vote.

In the rest of this paper we examine how often New York's vote was critical to a proposal passing or failing while its delegation was in attendance, and how often it could have been critical had it stayed past $10 \mathrm{July} .{ }^{9} \mathrm{We}$ also speculate on how different the final form of the Constitution would be if New York had left earlier, or if New York had remained throughout. The answer: not much. There were very few close calls at the Convention, and New York's presumed position on these votes would rarely have changed the outcome. This suggests the importance of Lansing's and Yates' departure costing New York its vote has been over-emphasized in affecting the outcome of the Constitutional Convention.

\section{Background}

Voting at the Convention was conducted by majority rule of the state votes where each state vote was determined by a majority of its present delegates.

7 Farrand, Max, The Records of the Federal Convention of 1787.

8 Dougherty, Keith L., and Jac C. Heckelman, "A Pivotal Voter from a Pivotal State: Roger Sherman at the Constitutional Convention" in American Political Science Review 100, (2006): 297-302.

9 Hereafter, New York's departure will refer to the departure of Lansing and Yates after 10 July. 
State votes were tallied from North to South beginning with Massachusetts and ending with Georgia (assuming, of course, these states were present). Passage of a proposal required a simple majority of the state votes to be in favor. Each of the state legislatures appointed several delegates although not all attended. New York appointed only three delegates to the Convention (less than any other state except Rhode Island which did not appoint any) and the state delegation was permitted to cast a vote as long as at least two delegates were present. ${ }^{10}$

The three delegates sent to the Convention by New York were Alexander Hamilton, John Lansing, and Robert Yates. Hamilton was born in the British West Indies and came to New York City in 1772 where, for a brief time, he stayed at the home of William Langston, who would later attend the Convention as a delegate from New Jersey. ${ }^{11}$ Hamilton was quick to participate in the revolutionary cause by writing a pamphlet entitled "A Full Vindication of the Measures of the Congress from the Calumnies of Their Enemies." During the Revolution Hamilton served as an aide-de-camp to General Washington and fought at the battle of Yorktown. After the Revolution Hamilton would enter the legal profession, and, even though he was an avowed nationalist, took up several cases defending the rights of loyalists. ${ }^{12}$ At only 30 years of age when the Convention began, Hamilton was one of the youngest delegates to attend. Hamilton's speaking style has been described as a passionate oratory who "delighted his supporters, but sometimes confirmed his opponent's suspicions and fears".13

Lansing and Yates were both appointed to represent New York at the Convention due to the influence of Governor George Clinton. Lansing was perhaps the wealthiest man in New York and had a lucrative law practice. ${ }^{14}$ During the Revolution, Lansing served as a military secretary to General Philip Schuyler. After leaving the military he would turn to policy, serving six terms in the New York Assembly (including two years as the Speaker), serving as Mayor of Albany, and sitting in the Confederation Congress for two years. Lansing was 32 years of age at the start of the Convention. William Pierce, a delegate from Georgia, described Lansing as having "a hesitation in his speech, that will

\footnotetext{
10 Farrand, Max, The Records of the Federal Convention of 1787 , vol. III, app. B.

11 Vile, John R., The Constitutional Convention of 1787: A Comprehensive Encylopedia of America's Founding, (Santa Barbara: ABC-CLIO, Inc., 2005).

12 Vile, The Constitutional Convention of 1787.

13 Maier, Pauline, Ratification: The People Debate the Constitution, 1787-1788, (New York: Simon \& Schuster, 2010), p. 347 .

14 Vile, The Constitutional Convention of 1787.
} 
prevent his being an orator of any eminence."15 Lansing and Yates were related by marriage, and, like Lansing, Yates was born in New York and practiced law. During his studies, Yates studied with William Livingston. Yates served as a city alderman, a member of the Committee of Safety, a member of the provincial Congress, and as a justice of the New York Supreme Court. During his time on the Court he was criticized for his fair treatment of loyalists; yet despite their often acrimonious relationship, Hamilton described Yates as "upright and respectable in his profession". ${ }^{16}$ Yates was an Antifederalist, and attended the Convention believing that the delegates would only consider revising the $\mathrm{Ar}$ ticles of Confederation. ${ }^{17}$

Once Lansing and Yates left the Convention after 10 July, New York was without any representation, Hamilton having (temporarily) departed a week and a half prior. By leaving, not only did Lansing and Yates lose their ability to vote, they cost New York its representation in total. Even when Hamilton returned in mid-August, he was not able to cast votes on the floor in the absence of any co-delegates, but did participate in debates and was appointed to serve on the Committee of Style which was charged with polishing the final draft of the Constitution. McFerren claims that "New York's secession from the Federal Convention undoubtedly had a significant impact" and Beeman notes that "Yates and Lansing's departure would strengthen the hand of the nationalists at the Convention, removing as it did two of the most implacable opponents of a strengthened government."18 Indeed, it has been estimated by Heckelman and Dougherty that the median state position at the Convention moved in the federalist direction immediately following New York's departure. ${ }^{19}$ To the extent that Lansing and Yates were both committed anti-Federalists, and held similar views on many issues, they controlled New York's vote whenever they agreed and would typically over-rule Hamilton's strongly nationalistic preferences. ${ }^{20}$ But for their absence to affect proposal outcomes, the vote of New York would need to be critical to that proposal.

15 Maier, Ratification, p. 347.

16 Young, The Democratic Republic of New York, p. 43.

17 Vile, The Constitutional Convention of 1787.

18 McFerren, Warren L, Birth of the Republic: The Origin of the United States, (Sanford, FL: Southern Liberty Press, 2005), p. 303; Beeman, Richard, Plain, Honest Men, p. 203.

19 Heckelman, Jac C., and Keith L. Dougherty, "A Spatial Analysis of Delegate Voting at the Constitutional Convention" in Journal of Economic History 73, (2013): 407-444.

20 Riker, William H, "The Lessons of 1787" in Public Choice 55, (1987): 5-34; Johnson, Calvin H., Righteous Anger at the Wicked States: The Meaning of the Founders' Constitution, (Cambridge: Cambridge University Press, 2005); Beeman, Plain, Honest Men, p. 302. 
The manner of voting utilized at the Convention treated each state equally, regardless of the size of its delegation, the size of the population it represented, the wealth within the state, or any other criteria. A state's vote was to be counted as "yea" if the proposal was supported by a majority of its present delegates, "nay" if it was opposed by a majority of its present delegates, and "divided" if there was equal support and opposition among its present delegates. A proposal would pass only if it received more "yea" than "nay" state votes. "Divided" state votes were recorded but were not counted toward determining the majority outcome. Note that this form of simple majority rule is not neutral in that a majority is required for passage but not for failure as a tie vote results in rejection of the proposal. ${ }^{21}$

A priori, because each state could cast only a single vote, each state had equal ability to influence roll call outcomes. But after any specific roll call, the only state votes that mattered were those that actually affected the outcome. Based on majority rule, a state's vote was critical if it favored a proposal that passed by a single vote, opposed a proposal that failed by virtue of a tie or a single vote, or cast a "divided" vote on a proposal that failed by virtue of a tie. In all other cases, changing a single state's vote would result in the same outcome of passage or failure. Similarly, a state's attendance on the proposal was critical if it favored a proposal that passed by a single vote or opposed a proposal that failed by virtue of a tie. Finally, a state's lack of attendance only mattered if it would have voted "nay" on a proposal that passed by a single vote (thereby creating a tie and causing the proposal to fail) or would have voted "yea" on a proposal that resulted in a tie (thereby breaking the tie in favor of the proposal passing).

In the next section we determine all the votes for which New York could have been critical, and the impact of New York's actual vote or potential vote would have had. Assessing actual votes is fairly straightforward but determining New York's expected votes during its absence requires some additional assumptions, as developed below.

\section{Identifying Critical Votes}

There were nearly 800 roll calls at the Convention. The CCRG dataset, developed from the four-volume set of Farrand, contains vote tallies on 620

21 Heckelman, Jac C., "A Note on Majority Rule and Neutrality with an Application to State Votes at the Constitutional Convention of 1787" in Public Choice 167 (2016): 245-255. 
substantive (i.e., not including procedural motions to postpone, adjourn, commit, or reconsider) motions. ${ }^{22}$ We limit our analysis to the 579 roll calls in the dataset for which individual state votes were recorded by the Secretary of the Convention and/or James Madison.

New York was present (i.e. had at least two delegates in attendance) in the CCRG data set for each of the first 127 roll calls except one. ${ }^{23}$ State votes were not recorded for six of these roll calls. Thus, there were 120 recorded roll calls for which New York was in attendance. As shown in Table 1, only 17 (15\%) of these roll calls were close enough such that one state changing its vote could possibly affect the outcome. In particular for New York, had Lansing and Yates never attended (perhaps joining Patrick Henry's boycott or if New York mimicked Rhode Island in never appointing delegates for the Convention), the loss of New York's vote would only have affected five of these roll calls - representing only $4.2 \%$ of the votes cast by New York.

An additional 492 substantive roll calls are contained in the CCRG dataset following New York's departure after 10 July. Of the 458 roll calls for which state votes were recorded, 43 were decided by a margin of only one or tied. Had New York remained, it had the potential to affect any of the 22 roll calls in which

TABLE 1 Close roll calls (\% of total roll calls)

\begin{tabular}{lllll}
\hline & $\begin{array}{l}\text { Total roll } \\
\text { calls }\end{array}$ & $\begin{array}{l}\text { Close roll } \\
\text { calls }\end{array}$ & $\begin{array}{l}\text { NY vote critical } \\
\text { when attending }\end{array}$ & $\begin{array}{l}\text { Counterfactual potential } \\
\text { for NY to be critical }\end{array}$ \\
\hline NY present & 120 & $17(15.0 \%)$ & $6(5.0 \%)$ & - \\
NY absent & $45^{8}$ & $43(9.4 \%)$ & - & $22(4.8 \%)$ \\
\hline
\end{tabular}

Notes: Close roll calls passed or failed by less than a two-vote margin. NY vote critical when present if it voted 'yea' and margin $=+1$ (pass) or voted 'nay' and margin $=0$ (fail). NY vote potentially critical in its absence when margin $=+1$ (pass) or margin $=0$ (fail). NY missed one vote (roll call 63 - not close) before Lansing and Yates left on 11 July. No state votes were recorded for 6 roll calls while NY present and 35 after NY left. These votes are not included in the total roll calls.

22 Dougherty, Keith L., and Jac C. Heckelman, Delegate Positions on All Substantive Roll Calls at the United States Constitutional Convention, 1787. Vols. ICPSR33865-v1, Ann Arbor, MI: Inter-university Consortium for Political and Social Research [distributor], 2012.

New York missed roll call 63 . 
the proposal passed by a single vote, or failed due to a tie. ${ }^{24}$ Thus, coincidently, New York had at most the potential to affect roughly the same percentage of votes (just under $5 \%$ ) after its departure as it did while present. If Lansing and Yates felt that their experience of influencing $4 \%$ of the votes was not reason enough to stay, they would be unlikely to have regretted missing the remaining votes unless those missed votes proved to be particularly important. We investigate the substance of these votes below.

\section{Determining Counter-factual NY Votes}

Whether New York's departure made a difference on close roll calls depends on how New York would have voted if Lansing and Yates had remained. If New York would have voted with the majority of states, the same outcome would occur but with a larger margin. New York's absence would be critical to a roll call outcome only if it would have voted in opposition to a proposal that passed by a single vote, or would have broken a tied vote in favor of the proposal. To estimate how New York would have voted if Lansing and Yates never left the Convention, we compare New York's record to other states.

Spatial analysis suggests the majoritarian ideological makeup of the New York delegation most closely resembled that of the New Jersey delegation. Although individual delegate votes were only rarely recorded by Madison, the CCRG dataset contains inferences on over 5,00o delegate votes. ${ }^{25}$ Based on the available inferences for a sample of 397 roll calls, Heckelman and Dougherty estimated spatial locations in a single dimension for each delegate, using the D-NOMINATE procedure for most delegates and imputations on the rest, and further highlighted positions for the median delegate (or co-median delegates for states with an even-sized delegation) of each state. ${ }^{26} \mathrm{~A}$ picture similar to their graphical presentation is represented here by Figure $1 .{ }^{27}$ The median New York delegate (Robert Yates) is the most extreme of all the state median

24 Proposals that failed by one vote would still fail no matter how NY voted had it been present.

25 Inferences are based on recorded debates and other methods, and represent roughly $25 \%$ of all the delegate votes on 620 substantive votes.

26 Heckelman, Jac C., and Keith L. Dougherty, "A Spatial Analysis of Delegate Voting at the Constitutional Convention".

27 States with an even number of attending delegates are represented by two points, for the left median (subscript 1) and right median (subscript 2) in that state. New Hampshire's only two delegates were estimated to have identical positions. 


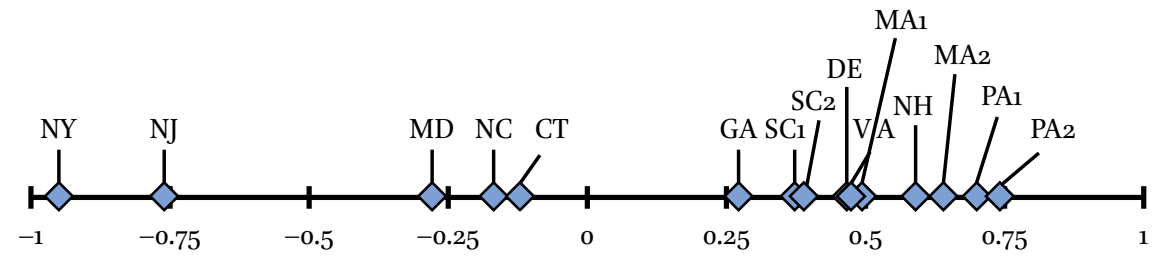

FIGURE 1 Median delegate(s) for each state

SOURCE: HECKELMAN AND DOUGHERTY (2013)

delegates, and is closest to the median delegate from New Jersey (William Livingston), who is the only other state median delegate on the far left of the distribution. ${ }^{28}$ This suggests that if all delegations are in full attendance, majority votes from New York would generally be more similar to that of New Jersey than any other state. New York's ideological spatial proximity to New Jersey is also observed in two-dimensions derived from the known state votes. Using the state votes collected by Jillson on 569 roll calls, Dougherty and Heckelman employ Optimal Classification on two-dimensions to estimate ideal points for the twelve states. ${ }^{29}$ Their graph is replicated in Figure $2 .{ }^{30}$ New York is again located at a fairly extreme position with the closest state being New Jersey and all others much further away. Based on these plots we determine that two different estimation techniques, using different samples, can be used to suggest a similar result, namely that missed New York votes should be predicted to most closely resemble New Jersey votes.

Spatial estimation is not without its critics, and various assumptions are required which may or may not be valid for the Convention. For example, there was never a vote on which all 55 delegates were present (as in Figure 1 which identifies only the median delegate in each state), and states do not have "ideal points" as such (as in Figure 2). We therefore also consider a simpler mechanism by comparing the percentage of times New York cast a vote that was the

28 Heckelman and Dougherty, "A Spatial Analysis of Delegate Voting at the Constitutional Convention," interpret the dimension to represent anti-Federalist/localist positions toward the left and Federalist/nationalist positions toward the right.

29 Jillson, Calvin, Constitution Making: Conflict and Consensus in the Federal Convention of 1787, (New York: Agathon Press, 1988); Dougherty and Heckelman, "A Pivotal Voter from a Pivotal State".

30 Dougherty and Heckelman, "A Pivotal Voter from a Pivotal State," interpret the first dimension to represent issues related to representation and the second dimension to represent issues related to centralization. 


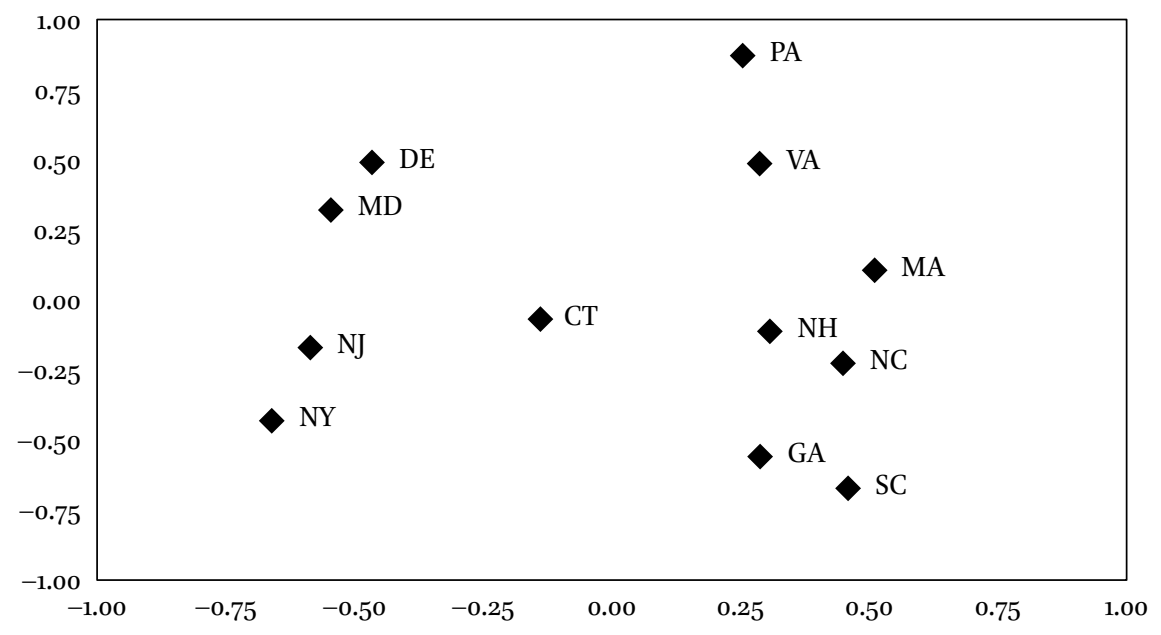

FIGURE 2 State ideal points in two dimensions

SOURCE: DOUGHERTY AND HECKELMAN (2006)

same as another state, presented in Table 2. In the upper panel we ignore any 'divided' votes, and only count those votes on which both states in a dyad voted 'yea' or 'nay'. ${ }^{11}$ In essence, a 'divided' vote is treated the same as not being in attendance. The lower panel treats voting 'divided' as a third alternative on which states can agree or disagree. As shown in panel A, of the 93 times New Jersey and New York both voted on the same roll call, ${ }^{32}$ they agreed on $79.6 \%$ of the votes. Percentages are lower across the board in panel B when including 'divided' votes in the comparisons, but New Jersey remains in agreement with New York on more than $70 \%$ of the votes. Although the number of roll calls analyzed in Table 2 is much smaller than the number of roll calls used to construct the spatial estimates, the proximity between New York and New Jersey in the one- and two-dimensional spatial representations are corroborated nonetheless. We therefore assume as our counter-factual that New York would have voted the same as New Jersey on roll calls after 10 July.

\footnotetext{
31 Agreement on voting 'divided' is not possible unless both state delegations happen to be comprised of an even number of delegates. There were also single votes for which Delaware (vote 3), Pennsylvania (vote 4), Georgia (vote 10o), and South Carolina (vote 100) were not recorded.

Again, other than 'divided'.
} 


\section{Panel A. "Divided" votes not included}

\begin{tabular}{llll}
\hline State & $\begin{array}{l}\text { Total rolls calls in attendance } \\
\text { when NY in attendance }\end{array}$ & \multicolumn{2}{l}{ roll calls voting the same as NY } \\
\cline { 3 - 4 } & & total & percent \\
\hline NJ & 93 & 74 & 79.6 \\
MD & 84 & 62 & 73.8 \\
DE & 104 & 75 & 72.1 \\
NC & 109 & 73 & 67.0 \\
GA & 102 & 68 & 66.7 \\
CT & 107 & 71 & 66.4 \\
VA & 110 & 69 & 62.7 \\
SC & 109 & 68 & 62.4 \\
MA & 104 & 63 & 60.6 \\
PA & 106 & 64 & 60.4 \\
NH & N/A & N/A & N/A \\
& & & \\
\hline
\end{tabular}

PanelB. "Divided" votes included

\begin{tabular}{llll}
\hline State & $\begin{array}{l}\text { Total rolls calls in attendance } \\
\text { when NY in attendance }\end{array}$ & \multicolumn{2}{l}{ roll calls voting the same as NY } \\
\cline { 3 - 4 } & & total & percent \\
\hline NJ & 101 & 74 & $73 \cdot 3$ \\
MD & 93 & 62 & 66.7 \\
DE & 114 & 76 & 66.7 \\
GA & 111 & 71 & 64.0 \\
NC & 119 & 73 & 61.3 \\
CT & 117 & 71 & 60.7 \\
VA & 120 & 69 & $57 \cdot 5$ \\
SC & 119 & 68 & 57.1 \\
MA & 114 & 66 & $57 \cdot 9$ \\
PA & 116 & 65 & 56.0 \\
NH & N/A & N/A & N/A \\
& & & \\
\hline
\end{tabular}

Note. Upper panel does not include 10 roll calls on which NY voted 'divided' or 12 roll calls for which no state votes were recorded. First column also does not include any roll calls for a state when it voted 'divided' or its vote was not recorded. DE vote not recorded on roll call 3 , PA vote not recorded on unnumbered roll following roll call 4, GA and SC votes not recorded on roll call 10o. Lower panel is the same except it includes all 'divided' state votes in both totals columns. 


\section{What if NY Remained and Voted the Same as NJ?}

Suppose now that Lansing and Yates remained at the Convention despite their misgivings. There were 22 roll calls recorded in the CCRG dataset after 10 July on which New York's absence might have been critical. However, New Jersey was absent for three of these roll calls so we do not predict New York's vote for those roll calls. Of the remaining 19 roll calls, New York casting an identical vote as New Jersey would have increased the margin of victory or defeat for eleven roll calls (i.e., the outcome would be unchanged) and would have reversed the outcome for eight roll calls. Thus we predict only a small number of votes where New York's absence was meaningful. There were eight roll calls on which we expect New York's presence would have reversed the outcome, and three additional roll calls for which this might also be expected if we knew how New Jersey would have voted had it not been absent as well. These results are summarized in Table 3 .

Table 4 identifies all roll calls that occurred after 10 July on which New York had the opportunity to be critical and the impact New York would have by voting the same as New Jersey. Table 5 provides a description of each roll call after 10 July for which New York would have changed the outcome under the assumption of voting the same as New Jersey. Despite potentially changing the outcome for eight roll calls after 10 July, half of those roll calls appear to have been of nominal (if any) importance to the final Constitution.

Roll call 440 addressed restrictions on members of the national legislature serving in civil offices. New York is assumed to have opposed the restrictions approved by roll call 440, but it is unclear what practical impact a nay vote would have had on the final constitution or the subsequent government. Roll call 520 dealt exclusively with rescinding the Convention rule that prevented adjournment before $3 \mathrm{pm}$. This vote had no impact on the content of the final

TABLE 3 Counterfactuals for potential of $N Y$ to affect 458 roll call outcomes had it stayed at the Convention

\begin{tabular}{lll}
\hline & \# of Roll calls & Percentage (out of 458) \\
\hline Potential critical votes & $22(\max )$ & 4.8 \\
NY assumed identical to NJ & $11(\max )$ & 2.4 \\
NY vote matched to known NJ vote & 8 (exact) & 1.7 \\
\hline
\end{tabular}

Notes: $\mathrm{NY}$ counterfactually potentially critical when true roll call margin $=0$ (fail) or +1 (pass). New Jersey did not vote on four of the roll calls for which NY was potentially critical. 
TABLE 4 Roll calls for which NY was potentially critical had it stayed

\begin{tabular}{|c|c|c|c|c|c|}
\hline $\begin{array}{l}\text { Roll call } \\
\text { number }\end{array}$ & Actual votes & $\begin{array}{l}\text { Actual } \\
\text { outcome }\end{array}$ & NJ's vote & $\begin{array}{l}\text { Counterfactual } \\
\text { votes }\end{array}$ & $\begin{array}{l}\text { Counterfactual } \\
\text { outcome }\end{array}$ \\
\hline 133 & $5^{-5}$ & Fail & Nay & $5^{-6}$ & Fail \\
\hline 139 & $5^{-5}$ & Fail & Nay & $5^{-6}$ & Fail \\
\hline 142 & $5^{-4}$ & Pass & Yea & $6-4$ & Pass \\
\hline 149 & $5^{-5}$ & Fail & Nay & $5^{-6}$ & Fail \\
\hline$\underline{150}$ & $5^{-4}$ & Pass & Nay & $5^{-5}$ & Fail \\
\hline $15^{6}$ & $5^{-4}$ & Pass & Yea & $6-4$ & Pass \\
\hline 176 & $4-4$ & Fail & - & - & - \\
\hline 236 & $5^{-5}$ & Fail & - & - & - \\
\hline$\underline{266}$ & $6-5$ & Pass & Nay & $6-6$ & Fail \\
\hline 291 & $5^{-5}$ & Fail & Nay & $5^{-6}$ & Fail \\
\hline 303 & $6-5$ & Pass & Nay & $6-6$ & Fail \\
\hline 311 & $4-4$ & Fail & - & - & - \\
\hline 326 & $6-5$ & Pass & Yea & $7-5$ & Pass \\
\hline 361 & $4-4$ & Fail & Yea & $5^{-4}$ & Pass \\
\hline 394 & $6-5$ & Pass & Yea & $7-5$ & Pass \\
\hline 402 & $6-5$ & Pass & Nay & $6-6$ & Fail \\
\hline 419 & $5^{-5}$ & Fail & Nay & $5^{-6}$ & Fail \\
\hline 439 & $5-5$ & Fail & Nay & $5^{-6}$ & Fail \\
\hline 440 & $5^{-4}$ & Pass & Nay & $5^{-5}$ & Fail \\
\hline 520 & $6-5$ & Pass & Nay & $6-6$ & Fail \\
\hline 533 & $6-5$ & Pass & Yea & $7-5$ & Pass \\
\hline 550 & $5^{-5}$ & Fail & Yea & $6-5$ & Pass \\
\hline
\end{tabular}

Notes. Underlined roll calls would have changed outcomes if NY was present and voted the same as NJ. See Table 5 for additional details on underlined roll calls.

constitution. Roll call 550 was essentially a non-vote - immediately following it the exact same motion was voted on again and passed without debate. ${ }^{33} \mathrm{~A}$ vote

33 Neither the final vote tally nor any specific state votes were recorded for the subsequent roll call, so we do not know why the votes changed, nor how many votes changed. Madison's journal entry reads: "The [first] motion being lost by equal division (of votes,) it was urged that it be put a second time, some such provision being too necessary, to be omitted, and on a second question it was agreed to nem. con." Farrand, The Records of the Federal Convention of 1787 , vol. II, pp. 627-8. 
TABLE 5 Roll call descriptions for which NY would have been critical if present and voted the same as $\mathrm{NJ}$

\begin{tabular}{|c|c|c|c|}
\hline $\begin{array}{l}\text { Roll } \\
\text { call }\end{array}$ & $\begin{array}{l}\text { Actual } \\
\text { outcome }\end{array}$ & Description of proposal & $\begin{array}{l}\text { Counterfactual } \\
\text { outcome }\end{array}$ \\
\hline $15^{0}$ & Passed & $\begin{array}{l}\text { Based taxation off the number of Representatives } \\
\text { each state has in the first meeting of the national } \\
\text { legislature until a census is conducted }\end{array}$ & Fail \\
\hline 266 & Passed & $\begin{array}{l}\text { A motion to reconsider the qualifications for } \\
\text { members of the House of Representatives with } \\
\text { the intent of reducing the citizenship require- } \\
\text { ment from seven years to three }\end{array}$ & Fail \\
\hline 303 & Passed & $\begin{array}{l}\text { Established that Congress would have the power } \\
\text { to establish post roads (in addition to establishing } \\
\text { post offices, which was already agreed to) }\end{array}$ & Fail \\
\hline 361 & Failed & $\begin{array}{l}\text { To establish that the President shall be chosen by } \\
\text { electors }\end{array}$ & Pass \\
\hline 402 & Passed & $\begin{array}{l}\text { Prohibited new states from arising from within } \\
\text { the borders of existing states without the consent } \\
\text { of the state legislature and the national legislature }\end{array}$ & Fail \\
\hline 440 & Passed & $\begin{array}{l}\text { Excluded sitting legislators from serving in those } \\
\text { federal offices that were created or given a pay } \\
\text { raise during the legislator's time in office }\end{array}$ & Fail \\
\hline $5^{20}$ & Passed & $\begin{array}{l}\text { Rescinded the rule specifying that the } \\
\text { Convention cannot adjourn before } 3 \mathrm{pm}\end{array}$ & Fail \\
\hline $55^{\circ}$ & Failed & $\begin{array}{l}\text { To allow Congress to vest the appointment of } \\
\text { officers in the President, courts, or in the heads } \\
\text { of departments }\end{array}$ & Pass \\
\hline
\end{tabular}

by New York on $55^{\circ}$ (assumed to be in favor) would have simply eliminated the need for the re-vote. A vote by New York on roll call 266 (assumed to be in opposition) would have prevented reconsidering the status quo of a seven year citizenship requirement for members of the House of Representatives. After the motion passed, a date was set for the reconsideration. On the date of reconsideration, four separate amendments were proposed (roll calls 282-285), all of which failed. The end result was thus the same as if roll call 266 had passed, simply saving the delegates the time spent debating and voting on these four 
failed proposals. In a similar vein, a 24 August vote by New York on roll call 361 (assumed to be in favor) would have resulted in the Convention agreeing to have electors choose the president, which eventually was reported by the Committee of Detail and agreed to on 6 September.

The remaining roll calls New York would have swayed were potentially important to the course of the Convention, the final constitution, and the subsequent national government. With a general agreement already in place that the first branch of the national legislature would be apportioned by population, the delegates took up the issue on 13 July of how taxes would be levied to cover the expenses of the federal government. Gerry motioned:

that from the first meeting of the Legislature $<$ of the U.s. $>$ till a census shall be taken all monies to be raised <for supplying the public Treasury> by direct taxation, shall be assessed on the inhabitants of the $<$ several $>$ States according to the $<$ number of their $>$ Representatives $<$ respectively $>$ in the $1^{\text {st }}$ branch $^{34}$

Gerry's motion was defeated by a vote of four to six. Several delegates raised concerns about referencing inhabitants, which would not be totally known until a census was conducted. Accordingly, Gerry put forth a new motion (roll call 150):

That from the $1^{\text {st }}$ meeting of the Legislature of the U.s. until a census shall be taken, all monies for supplying the public Treasury by direct taxation shall be raised from the several states according to the number of their representatives respectively in the 1 st. branch ${ }^{35}$

The delegates had already agreed on the previous day that a census would be conducted, so the heart of roll call 150 is the method of levying taxes in the first meeting of the national legislature. Roll call 150 passed by a vote of five to four, with Pennsylvania casting a divided vote. New Jersey cast a nay vote, so we predict New York's participation would have resulted in the motion failing. Had New York been in attendance for roll call 150 the delegates would have needed to determine a new method for levying direct taxation until a census could be taken. A likely alternative for discussion might have been levying direct taxes based on the value of state exports or imports; however, such discussions might have called into question apportionment in the first branch of the

34 Farrand, The Records of the Federal Convention of 1787 , vol. I, pp. 6oo-6o1.

35 Farrand, The Records of the Federal Convention of 1787 , vol. I, p. 6o3. 
national legislature. During the debate preceding roll call 150, General Pinckney specified "S. Carolina has in one year exported the amount of $£ 600,000$ Sterling all which was the fruit of labor of her blacks. Will she be represented in proportion to this amount? She will not. Neither ought she then be subject to a tax on it."36 If the method of levying taxes had evolved into a discussion on imports and exports, some states might have demanded that apportionment be based on those measures.

On 16 August, the delegates considered several powers that the Constitution would ultimately vest in Congress. When considering Congress's power to establish post offices, Gerry moved to grant Congress the power to establish post roads as well (roll call 303). The motion passed by a vote of six to five, with New Jersey casting a nay vote. The motion would have likely failed had New York voted. Granting Congress the power to establish post roads might mean Congress could construct new roads for the purposes of delivering the mail. If so, the post roads clause granted the federal government the exact type of power that Lansing and Yates loathed so much. The issue was not discussed at the Convention, but has been touched on by several subsequent Supreme Court rulings.

In Searight v. Stokes (1845), the Supreme Court ruled that mail carriages were exempt from paying tolls. In a dissenting opinion, Justice Daniel stated "I believe that the authority vested in Congress by the Constitution to establish post roads confers no right to open new roads, but implies nothing beyond a discretion in the government in the regulations it may make for the Post Office Department for the selection amongst various routes." In 1855, Justice McLean, writing for the majority in United States $v$. Railroad Bride Co, stated that the power to establish post roads "has generally been considered as exhausted in the designation of roads on which the mails are to be transported." However, in Kohl v. United States (1875), the Supreme Court first took up the issue of federal eminent domain when a landowner challenged the federal government's acquisition of land in Ohio for use as, among other things, a post office building. In the opinion of the court, Justice Strong stated:

The powers vested by the Constitution in the general government demand for their exercise the acquisition of lands in all the States. These are needed for forts, armories, and arsenals, for navy-yards and light-houses, for custom-houses, post-offices, and court houses, and for other public uses

$36 \quad$ Farrand, The Records of the Federal Convention of 1787 , vol. I, p. 592. 
By explicitly including the establishment of post roads as a congressional power, the Constitution opened the door for eminent domain to be used in the establishment of roads required to deliver mail. Perhaps if New York had remained at the Convention, this is the one case in which it could have prevented the insertion of a clause that ultimately lead to a more powerful federal government.

Roll call 402 occurred within a broader debate on the process of admitting new states into the union. The Committee of Detail, a committee charged with taking everything that had been agreed to at the Convention and working it into a rough draft of a constitution, reported the following:

New States lawfully constituted or established within the limits of the United States may be admitted, by the Legislature, into this Government; but to such admission the consent of two thirds of the members present in each House shall be necessary. If a new State shall arise within the limits of any of the present States, the consent of the Legislatures of such States shall be also necessary to its admission. If the admission be consented to, the new States shall be admitted on the same terms with the original States. But the Legislature may make conditions with the new States, concerning the public debt which shall be then subsisting ${ }^{37}$

This clause was considered on 29 August. The delegates agreed to strike out the last two sentences (roll call 401), at which point Gouvenour Morris proposed the following substitute:

New States may be admitted by the Legislature into this Union: but no new state shall be erected within the limits of any present States, without the consent of the Legislature of such State, as well as of the Genl. Legislature $^{38}$

After the floor agreed to the first part of Morris's proposal, up to the word Union, the states voted on the remaining wording (roll call 402). The outcome was six states in favor and five against, with New Jersey voting no. The next day the chamber considered the entire substitute and, after nominal tweaks, approved it. If New York had voted the same as New Jersey, then roll call 402 would have resulted in a tie. In such a case, the requirements reported by the

37 Farrand, The Records of the Federal Convention of 1787 , vol. II, p. 188.

38 Farrand, The Records of the Federal Convention of 1787 , vol. I, p. 455 . 
Committee of Detail, as amended by roll call 401, would have prevailed requiring a $2 / 3$ rds majority in the national legislature for new states to be admitted. ${ }^{39}$

\section{What if NY Never Attended?}

Lansing and Yates did not like the direction of the Convention. They were supporters of the "New Jersey plan" which proposed specific amendments to the Articles of Confederation (such as creation of a multi-person executive) but kept intact the treatment of equality among all the states in national deliberation through a unicameral legislature where each state had a single vote, and limited powers of a national government. Had they known the Convention would instead adopt the "Virginia plan" as its new framework (which included a bicameral legislature based on proportional representation and expanded federal powers), in essence throwing away the Articles and debating revisions within Madison's framework, they may have boycotted from the start, similar to Patrick Henry. Had Lansing and Yates never attended, or at least left earlier than they did, the outcomes of roll calls while they were in attendance might have been affected. ${ }^{40}$

Recall from Table 1 that New York's vote was critical to the outcome of five roll calls $(4.2 \%)$ while in attendance. Details are presented in Table 6 and Table 7 for actual and counterfactuals on these votes. Lansing did not arrive at the Convention until 6 June (roll call 29) and thus only missed two votes (roll calls 1 and 9) for which New York's vote was critical. His individual absence was irrelevant because Yates and Hamilton voted in agreement on those two roll calls. But if Yates was also absent, New York would have lost its vote altogether and these outcomes would have been reversed.

The first roll call may have been the most important, as it set the tone for the Convention. A motion had been made to declare "that a union of the States, merely federal, will not accomplish the objects proposed by the Articles of Confederation, namely 'common defence, security of liberty, and general welfare," in essence justifying the consideration of a new national government

39 We note that statehood for Alaska passed in the House of Representatives by only a 186146 margin, surpassing the required majority threshold but falling short of $2 / 3$-majority.

40 It is certainly possible the New York state legislature may have authorized other delegates to take their place had they refused to attend, but we remind readers it did not choose to replace them after they left causing New York to lose its vote at the Convention. Perhaps our counter-factual here is more reasonable if we simply assume they did initially attend but simply left much sooner. 
TABLE 6 Roll calls for which NY's attendance and vote were critical

\begin{tabular}{llllll}
\hline $\begin{array}{l}\text { Roll call } \\
\text { number }\end{array}$ & $\begin{array}{l}\text { Actual } \\
\text { votes }\end{array}$ & $\begin{array}{l}\text { Actual } \\
\text { outcome }\end{array}$ & NY's vote & $\begin{array}{l}\text { Counterfactual } \\
\text { votes }\end{array}$ & $\begin{array}{l}\text { Counterfactual } \\
\text { outcome }\end{array}$ \\
\hline 1 & $4^{-4}$ & Fail & Nay & $4-3$ & Pass \\
9 & $5^{-4}$ & Pass & Yea & $4-4$ & Fail \\
80 & $5^{-5}$ & Fail & Nay & $5^{-4}$ & Pass \\
90 & $5^{-5}$ & Fail & Nay & $5^{-4}$ & Pass \\
92 & $5^{-5}$ & Fail & Nay & $5^{-4}$ & Pass \\
\hline
\end{tabular}

TABLE $7 \quad$ Roll call descriptions for which NY's attendance and vote were critical

\begin{tabular}{|c|c|c|c|}
\hline Roll call & $\begin{array}{l}\text { Actual } \\
\text { outcome }\end{array}$ & Description of proposal & $\begin{array}{l}\text { Counterfactual } \\
\text { outcome }\end{array}$ \\
\hline 1 & Failed & $\begin{array}{l}\text { To postpone consideration of proposal for } \\
\text { establishing a "supreme" national government } \\
\text { comprised of legislative, judicial, and executive } \\
\text { branches, in favor of "a more effective" } \\
\text { government consisting of the same. }\end{array}$ & Pass \\
\hline 9 & Passed & $\begin{array}{l}\text { To establish that the national executive shall } \\
\text { serve a seven year term. }\end{array}$ & Fail \\
\hline 80 & Failed & $\begin{array}{l}\text { To establish that national legislators will be } \\
\text { paid adequate compensation to be paid out of } \\
\text { the us Treasury. }\end{array}$ & Pass \\
\hline 90 & Failed & $\begin{array}{l}\text { To establish that members of the upper } \\
\text { chamber of the us legislature would serve six } \\
\text { year terms. }\end{array}$ & Pass \\
\hline 92 & Failed & $\begin{array}{l}\text { To establish that members of the upper } \\
\text { chamber of the us legislature would serve five } \\
\text { year terms. }\end{array}$ & Pass \\
\hline
\end{tabular}

structure. It was then proposed by Pierce Butler (sc) that the new national government be comprised of a "supreme" legislative, judiciary, and executive giving them authority over the states. Prior to voting on that proposal, George Read (DE) motioned to instead vote on a resolution by Edmund Randolph (VA) which referred only to "a more effective government" consisting of those three 
branches but without reference to them being collectively "supreme". Read's motion, which became the first recorded roll call, ${ }^{41}$ failed by virtue of a tied vote (4-4) with New York (Hamilton and Yates) voting no. If Yates had missed this first vote (along with Lansing), then Read's motion would have passed. When Read's motion failed, Butler's proposal passed easily (6-1-1) despite Yates' vote in opposition (with Hamilton voting in favor resulting in a divided vote by New York). ${ }^{42}$ Thus, Yates' presence ultimately led to passage of a clause establishing the national government to be "supreme" which he probably found more objectionable to declaring the new government "more effective" than the national institutions created by the Articles of Confederation. Perhaps this represents a paradoxical example where a voter might have been better off abstaining rather than voting.

New York also played a critical role early on for establishing the electoral term length of the president. However, this result proved fleeting. Without New York's vote, roll call 9 establishing the term length of seven years would have failed. Although seven years was initially agreed to by the Convention, the issue was reconsidered along with whether reelection was to be allowed, or whether election was to take place by the legislature or electors. In a final series of votes taken long after New York's departure (roll calls 453-455), proposals for term lengths of seven and then six years were both rejected before a term length of four years was passed by a nearly unanimous vote of 10-1 (North Carolina being the lone negative vote). There is little reason to expect these votes would not still have taken place had the initial proposal of seven years failed. Thus, the outcome of roll call 9 was likely to have been inconsequential to what appears in the final Constitution.

Despite being critical on preventing the establishment of length of electoral term in the Senate, first for six years (roll call 9o) and then for five years (roll call 92) on the last two votes prior to adjourning for the day (the roll call between was a failed motion to adjourn), the matter was reconsidered at the start of the very next day and, after rejecting a nine year term, a six year term along with one-third replacement every two years was adopted (over the objection of New York) in roll call 94. If New York had been absent the day before, roll call go would have been expected to pass resulting in the same term length but without staggered terms. ${ }^{43}$

41 There is some controversy on this. See the discussion by Farrand, The Records of the Federal Convention of 1787 , vol I, p. $32 \mathrm{n} 6$.

On this occasion, Madison recorded the individual votes for Yates and Hamilton as reported in Farrand, The Records of the Federal Convention of 1787 , vol. I, p. 35.

43 Passage of roll call go would have made it unlikely for roll call 92 to be proposed. 
New York was also initially critical to rejecting the proposal (roll call 8o) that national legislators be paid "adequate compensation" instead of "fixed stipends". In roll call 97, "fixed stipend" was replaced by "compensation" with New York supporting. Roll call 97 would not have been necessary had New York not participated in the Convention. New York's absence for roll call 80 would have resulted in members of the national legislatures being paid "adequate compensation" instead of simply "compensation." The New York delegation clearly was opposed to "adequate compensation" over "compensation", but we are unable to ascertain specifically why they objected to the term "adequate". Ultimately the Constitution simply states that "the Senators and Representatives shall receive a Compensation for their Services, to be ascertained by Law..." Although New York prevailed on this issue, its importance is unclear.

\section{New York and the Great Compromise}

Our analysis has treated tied roll calls the same as defeated roll calls because the proposal fails in both circumstances. This treatment is reasonable for all tied roll calls except one: roll call 110. With equitable representation in the first branch of the national legislature already agreed to, roll call 110 was on the question of whether there would be equal representation in the second branch. Roll call 110 was ultimately a tie, with five states voting in favor, five states voting against, and one state casting a divided vote. This roll call is unique in that the tie resulted in the immediate formation of a committee to develop a compromise on the issue of apportionment in the national legislature. The committee ultimately proposed the "Great Compromise", which supposedly saved the Convention from collapse. ${ }^{44}$

Going into the Convention, delegates understood that representation in the future government would be a contentious issue. The small state coalition (New York, New Jersey, Connecticut, Delaware, and Maryland) wanted to continue the rule of one-state-one-vote that was established under the Articles. The large state coalition (Massachusetts, Pennsylvania, Virginia, North Carolina, South Carolina, and Georgia) wanted representation based on population, or a similar equitable ratio. North Carolina and Georgia had small populations but anticipated population booms in the near future.

Having already agreed on representation based on population in the first branch, Oliver Ellsworth (Ст) moved, on 2 July, that each state would have one vote in the second branch of the national legislature (roll call 110). One by one, 
states cast their vote in alignment with their coalition - each state from the small state coalition was voting yea and each state from the large state coalition was voting nay. After South Carolina voted nay, the tally was 5-5 with Georgia set to cast the tiebreaking vote. Only two delegates from Georgia, Abraham Baldwin and William Houstoun, were in attendance for the roll call. Madison recorded the former as being in support of the roll call and Houstoun being opposed. With Georgia's two delegates unable to reach an agreement, George cast a state vote of divided. The Convention was deadlocked.

Sensing the gravity of the situation, Charles Cotesworth Pinckney (sc) proposed forming a grand committee of a member of each state to reach a compromise on the issue of apportioning the national legislature (Committee on Representation, hereafter). The motion to commit passed. The debates surrounding the motion to commit indicate that delegates believed a committee was the only option on the table for reaching a compromise. For example, Gouverneur Morris "thought a Come. Advisable as the Convention had been equally divided." 45 Similarly, CC Pinckney stated "some compromise seemed to be necessary: the States being exactly divided." ${ }^{\prime 6}$ On 5 July the Committee on Representation offered its report, which established proportional representation in the first branch and equal representation in the second branch. The Great Compromise was finally reached on 16 July, and the Convention was able to move forward.

Holding all other state votes constant the absence of New York for roll call 110 would have resulted in four states voting in favor, five states voting opposed, and one state casting a divided vote. The roll call would have been defeated by majority preference. Would such an outcome have resulted in the subsequent formation of a committee? We cannot say definitively, but believe it is unlikely. Several delegates who supported the motion to commit referenced that the Convention was deadlocked and in need of saving, whereas a motion failing because more states voted nay than yea would not be treated as a deadlock. The results of not forming the Committee on Representation might have been catastrophic for the Convention as it was largely responsible for ushering through the Great Compromise. If roll call 110 had failed outright, it is possible the small state coalition would have walked away from the Convention. ${ }^{47}$ The collapse of the Convention would have meant a return to the Articles of Confederation (as status quo), which is what Lansing and Yates wanted all along.

\footnotetext{
45 Farrand, The Records of the Federal Convention of 1787 , vol. I, p. 511.

46 Farrand, The Records of the Federal Convention of 1787 , vol. I, p. 511.

47 Stewart, David O., The Summer of 1787: The Men Who Invented the Constitution, (New York: Simon \& Schuster, 2007); Beeman, Plain, Honest Men, pp. 187-188.
} 
Ironically, their decision to stay at the Convention as long as they did may have actually saved the Convention making them worse off. This may be another example of the "abstention paradox" applying to Lansing and Yates.

\section{Conclusions}

New York was the only state to lose its voting privilege at the 1787 Constitutional Convention, when two of its delegates, Lansing and Yates, permanently left the convention on 10 July. We conduct a formal analysis of the impact of the presence and absence of New York on affecting the clauses which were considered for the Constitution. We use the simple assumption that New York was critical to the outcome of a roll call vote if it favored a proposal that passed by a single vote, opposed a proposal that failed by virtue of a tie or a single vote, or cast a "divided" vote on a proposal that failed by virtue of a tie.

In this framework we find the overwhelming majority of votes cast by the New York delegation simply did not matter. New York was in attendance for all but one of the first 127 roll calls, but there was no recorded vote for six of those. Of the remaining 120 roll calls, New York's state vote impacted the outcome for only five roll calls.

We further explore the potential impact of Lansing and Yates leaving the Convention by developing the counterfactual for how they would have voted on later issues had they stayed. Our presumption is New York's vote would have matched that of New Jersey, based on both spatial analysis developed by Heckelman and Dougherty, ${ }^{48}$ and our own comparison of the coincidence of voting among all the states when New York did cast a vote. Similar to New York rarely being critical prior to their departure, we find that New York would have only been critical for eight out of 497 roll calls had Lansing and Yates remained. Furthermore, most of these eight roll calls were relatively inconsequential. Our counterfactual analysis suggests that the Constitution was not greatly altered by New York's absence.

Surprisingly, our analysis indicates that Lansing and Yates might have actually been better off never attending at all and keeping New York out of the Convention entirely just like Rhode Island. We mean better off not in the sense of saving lost time, but better off in that the Convention outcome might have been better aligned with their preferences had they never attended. The Convention's tone might have been entirely different had the very first roll call not

48 Heckelman and Dougherty, "A Spatial Analysis of Delegate Voting at the Constitutional Convention". 
failed, and it would have passed without New York's negative vote. Upon rejecting a statement calling for a new national government consisting of legislative, executive and judicial branches, which was a substitute motion, the previously tabled motion calling for the same three branches but that they would be "supreme" over the states, was then passed despite New York's vote. The rest of the discussion and issues raised at the Convention might have been entirely different had it not been decided so early that the states would be subservient to the new national government, a position in direct conflict with the general views of Lansing and Yates. Given their strong objections to the new Constitution and the powers it granted the federal government over the states, and initial support for the New Jersey plan which more closely resembled the Articles of Confederation, Lansing and Yates would likely have preferred either a very different document to have been drafted at the Convention or perhaps none at all, which would then keep the Articles in place. 